\title{
INTERMEDIATE EQUAL PROTECTION SGRUTINY OF WELFARE LAWS THAT DENY SUBSISTENCE
}

\section{INTRODUCTION}

The equal protection clause of the fourteenth amendment provides that "[n]o State shall . . . deny to any person within its jurisdiction the equal protection of the laws." The Supreme Court has never interpreted this provision to require that a statute treat every person identically in all circumstances: statutory classifications are not per se unconstitutional. ${ }^{2}$ Rather, the Court has held that different types of statutory classifications must be subjected to different standards of review. ${ }^{3}$ The lowest level of equal protection review, generally applicable to economic and social welfare legislation, requires that the statutory classification be rationally related to the statutory goal. ${ }^{5}$ The Court exercises a more exacting standard of review, however, when the law employs a "suspect" classification such as race or national origin, ${ }^{6}$ or infringes upon a "fundamental right" such as the right to interstate travel. ${ }^{2}$ If the law discriminates against such a suspect group or trenches upon a fundamental right, then the Court employs "strict" equal protection scrutiny, requiring that the statutory classification be necessary to further a compelling state interest. ${ }^{8}$

1 U.S. ConsT. amend. XIV, \& 1.

2 See Plyler v. Doe, 457 U.S. 202, 216 (1982) ("The Constitution does not require things which are different in fact or opinion to be treated in law as though they were the same.") (quoting Tigner v. Texas, 310 U.S. 141, 147 (1940); see also Royster Guano Co. v. Virginia, 253 U.S. 412, 415 (1920) ('TT]he 'equal protection of the laws' required by the Fourteenth Amendment does not prevent the States from resorting to classification for the purposes of legislation.").

- See generally G. Gunther, Constitutional Law 670-971 (10th ed. 1980 \& Supp. 1983); L. Tribe, American Constitutional Law $\$ \S 16-1$ to 16-57, $991-$ 1136 (1978 \& Supp. 1982). For an extensive list of sources that discuss modern equal protection caselaw, see Recent Developments, Constitutional Law-Equal Protection-A Texas Statute Which Withholds State Funds for the Education of Illegal Alien Children and Permits Local School Districts to Deny Enrollment to Such Children Does Not Further a Substantial State Interest and Therefore Violates the Equal Protection Clause of the Fourteenth Amendment, 28 VILL. L. REv. 198, 202 n.19 (1982).

- See, e.g., Dandridge v. Williams, 397 U.S. 471, 485 (1970).

Id. at 485-87.

- See e.g., Loving v. Virginia, 388 U.S. 1, 11 (1967) (Virginia statute prohibited marriage between blacks and whites); Hernandez v. Texas, 347 U.S. 475, 479 (1954) (selection process for jury service excluded Americans of Mexican descent).

7 Shapiro v. Thompson, 394 U.S. 618, 634 (1969).

- See, e.g., Kramer v. Union Free School Dist. No. 15, 395 U.S. 621, 627 (1969). 
The level of review a court chooses to apply is extremely important because it often determines the outcome of a given case. Strict scrutiny creates a strong presumption that the statute is unconstitutional. Rationality scrutiny, on the other hand, is a much more deferential standard of review under which a statute can easily pass constitutional muster. ${ }^{\circ}$

In Dandridge $v$. Williams, ${ }^{10}$ the Supreme court held that equal protection challenges to welfare legislation would be reviewed under the most deferential version of the rational relationship test: the welfare statute must be upheld so long as the statutory classification could conceivably be related to the statutory goal. ${ }^{11}$ This decision has made successful equal protection challenges to discriminatory welfare laws almost impossible, regardless of how harsh or arbitrary a law may be. ${ }^{12}$

Courts have not been uniformly satisfied with the constraints the Dandridge doctrine has placed on them. In 1983, the Court of Appeals for the Third Circuit in Price $v$. Cohen ${ }^{13}$ reviewed an equal protection challenge to a recently enacted Pennsylvania welfare statute. ${ }^{14}$ The statute classified recipients between the ages of eighteen and forty-five as "transitionally needy" unless they fit into certain exceptions. Those who fit into these exceptions and those over forty-five years old were classified as "chronically needy." While the chronically needy were entitled under the statute to year-round public assistance, the transitionally needy were eligible for benefits for only three months of each year.

For a succinct description of the "two-tier" framework of equal protection analysis in which the Court applied either "strict" or "rationality" scrutiny, see San Antonio Indep. School Dist. v. Rodriguez, 411 U.S. 1, 16-17 (1973).

- See Gunther, The Supreme Court, 1971 Term-Foreword: In Search of Evolving Doctrine on a Changing Court: A Model For a Newer Equal Protection, 86 HARv. L. REv. 1, 8 (1972).

10397 U.S. 471 (1970).

11 Id. at 485-87. In Dandridge, the Court rejected an equal protection challenge to a Maryland welfare law that set a maximum limit for AFDC grants to families above a certain size, regardless of the number of additional children. Under the statute, large families received smaller AFDG payments per child than small families, even when the children were equally needy. Id. at 477-78; see also id. at 490 (Douglas, J., dissenting). The Court held that this disparate treatment did not violate the equal protection clause since the statute was "rationally based." Id. at 485-87.

The Court explicitly held that this deferential standard of equal protection review should be applied even though welfare laws involve "the most basic economic needs of impoverished human beings." Id. at 485. The Court stated, "[T]he intractable economic, social, and even philosophical problems presented by public welfare assistance programs are not the business of this Court." Id. at 487.

12 Although this is generally true, the Court has indicated some reluctance in applying Dandridge to particularly harsh laws. See infra notes 125-32 and accompanying text.

13715 F.2d 87 (3d Cir. 1983).

14 Id. at $89-90$. 
The statute eliminated public assistance to the transitionally needy for nine months of each year. ${ }^{15}$

Considering itself bound by the language of Dandridge, ${ }^{16}$ the Third Circuit felt compelled to apply minimum rationality scrutiny, even though it expressed "considerable doubt about the appropriateness of the extremely deferential approach taken by the Supreme Court."17 The court reluctantly upheld the challenged statute as constitutional, on the grounds that it had a conceivable rational basis. ${ }^{18}$

When the Third Circuit heard the case, approximately 60,000 to 90,000 transitionally needy Pennsylvania residents faced a cut-off of their benefits after three months. ${ }^{19}$ The Price court found that those recipients being cut off had no adequate alternative source of public welfare and that private charities were unable to assist the indigents on a long-term basis. Since the recipients tended to be unskilled and to have a poor work history, their employment prospects were bleak. ${ }^{20}$ Affidavits submitted by public welfare and private charity administrators stated that many of the transitionally needy who had been cut off had no means by which to pay for food or rent and were thus forced to survive in the streets. ${ }^{21}$ The Price court observed that one of the named plaintiffs faced the "possibility that she would be forced out into the streets for the entire last trimester of her pregnancy." The court noted the statute's harsh effects: "At a time when her health and nourishment are of exceptional importance to her child's development, a pregnant woman is denied assistance."22

The statute's denial of welfare thus threatened an interest in bare subsistence. Because of the nature of the interest involved, the Third Circuit thought a searching inquiry into the statutory classification was needed. The Court asserted that "[w]ere this a matter of first impression, we might conclude that subsistence is impliedly protected by the Constitution, because it is of basic human importance and fundamental

15 Id.

${ }^{18} \mathrm{Id}$. at 94.

17 Id. at 96. See also id. at 94-96.

$18 \mathrm{Id}$. at 96.

10 Brief for Appellees at 2 n.1, Price v. Cohen, 715 F.2d 87 (3d Cir. 1983) [hereinafter cited as Brief for Appellees].

${ }^{20}$ Price, 715 F.2d at 90-91.

21 See Appeal from the Order of the United States District Court for the Eastern District of Pennsylvania, Appendix, at 113a-126a, Price v. Cohen, 715 F.2d 87 (3d Cir. 1983) [hereinafter cited as Appendix]; see also Price, 715 F.2d at 90-91.

${ }^{22} 715$ F.2d at 91 . Pennsylvania has since made some policy changes to rectify this situation. Women expecting their first child are now eligible for the AFDC program during the last three months of pregnancy. See Philadelphia Inquirer, March 3, 1984, at $\mathrm{B} 1$, col. 6 . 
to the meaningful exercise of all other rights." ${ }^{23}$ Finding Dandridge on point, however, the court upheld the statute under a rational basis standard.

This Comment will argue that in certain situations like Price courts should not feel bound by Dandridge to apply minimal scrutiny to harsh and arbitrary welfare laws. Traditional equal protection theory has changed considerably since the Dandridge decision in $1970 .^{24}$ Courts are no longer bound by two rigid tiers of scrutiny. In recent years, there has developed an intermediate level of equal protection review that requires more of a statutory classification than a mere rational relationship, but that is less demanding than the strict scrutiny standard. Under this middle tier of review, a statutory classification must be substantially related to an important state interest. ${ }^{25}$ When a statute discriminatorily denies subsistence ${ }^{26}$ to what this Comment will define as a "sensitive" class, intermediate scrutiny can and should be applied.

In support of this thesis, part I of the Comment will trace the Supreme Court's development of intermediate scrutiny to show that generally, when a law discriminates against a class with certain characteristics, the Court will apply heightened scrutiny. Part I will also attempt to identify these triggering characteristics and to define a sensitive class as one possessing one or more of these characteristics. Finally, part I will consider a recent innovation suggested by the 1982 Supreme Court case Plyler $v$. Doe $e^{27}$ : in certain cases a combination of factors may be necessary to justify the application of heightened scrutiny. In these cases the sensitive status of a group may not, by itself, be sufficient to justify the application of intermediate scrutiny. However, when this group has been denied an interest that is both important and has a close nexus with the exercise of constitutional rights, such heightened scrutiny is triggered.

Part II of the Comment will show how the Plyler principle, when applied to welfare laws, can be used by courts to invoke intermediate scrutiny when these laws discriminatorily deny subsistence to sensitive classes. It will also explain how this application is not inconsistent with the mandate of Dandridge and its progeny. Finally, part III of the Comment will apply the theory derived from Plyler to Price $v$. Cohen to demonstrate the practical difference such a principle can make in the

${ }^{23}$ Price, 715 F.2d at 93.

24 See infra notes 28-54 and accompanying text.

25 Craig v. Boren, 429 U.S. 190, 197-99 (1976).

26 For this Comment's definition of subsistence, see infra text preceding note 94.

27457 U.S. 202 (1982). 
outcome of a case.

\section{Development of Intermediate Equal Protection ScRutiny}

\section{A. Traditional Theory: The Development of the Sensitive Classification}

Traditionally, ${ }^{28}$ the Court has applied two levels of equal protection scrutiny: strict review of laws that discriminate against suspect classes or encroach on fundamental rights and rationality review for all other laws. ${ }^{29}$ In the 1970's and early 1980's, without explicitly stating that it was developing a new tier of equal protection review, ${ }^{30}$ the Court began to apply a heightened level of scrutiny to cases involving statutory discrimination against certain kinds of groups, particularly women and illegitimate children.

The standard applied to these groups is noticeably more rigorous than rationality scrutiny and requires the state to produce "credible supporting evidence" that demonstrates a substantial relationship between the statutory classification and the statutory goal. ${ }^{31}$ In contrast, under the rationality standard, a statutory classification that has a conceivable rational basis will pass equal protection muster, even though the state never produces evidence, by statistics or otherwise, supporting the choice of that particular classification. ${ }^{\mathbf{3 2}}$ Thus, "pure speculation" by the legislature will suffice under the rationality standard, ${ }^{33}$ but not

28 "Traditionally" refers to the Warren Court era (admittedly a short time horizon). See G. GUNTHER, supra note 3, at 671-72. For a description of traditional, twotier equal protection doctrine, see Hetherton v. Sears, Roebuck \& Co., 493 F. Supp. 82, 87-88 (D. Del. 1980).

39 See, e.g. San Antonio Indep. School Dist. v. Rodriguez, 411 U.S. 1, 17 (1973).

so See infra notes $40-49$ and accompanying text.

31 Plyler v. Doe, 457 U.S. 202, 229 (1982) (quoting In re Alien Children Educ. Litig., 501 F. Supp. 544, 583 (S.D. Tex. 1980), aff $d$ sub nom. Plyler v. Doe, 457 U.S. 202 (1982)); see also id. at 229 ("State must support its selection of this group as the appropriate target for exclusion"); id. at 230 (rejecting state's claim that statute served a substantial interest by reasoning that "it is an interest that is most difficult to quantify"); Craig v. Boren, 429 U.S. 190, 200-04 (1976) (analyzing at length and then rejecting as too weak statistical evidence purporting to show a relationship between statutory classification and goal).

32 See Vance v. Bradley, 440 U.S. 93, 111 (1979) ("[T]hose challenging the legislative judgement must convince the court that the legislative facts on which the classification is apparently based could not reasonably be conceived to be true by the governmental decisionmaker."); see also id. at 110 n.28 ("The State is not compelled to verify logical assumptions with statistical evidence." ") (quoting Hughes v. Alexandria Scrap Corp., 426 U.S. 794, 812 (1976)); Dandridge v. Williams, 397 U.S. 471, 485 (1970).

ss Vance v. Bradley, 440 U.S. 93, 111 (1979) (quoting Firemen v. Chicago, R.I. i \& P.R. Co., 393 U.S. 129, 138-39 (1968)) (The District Court does not have authority 
under the intermediate standard.

Although a majority of the Supreme Court has not explicitly recognized the existence of "sensitive" classes, the Court's application of this heightened scrutiny to laws that employ gender and legitimacy classifications indicates that the Court will de facto treat a class as sensitive if it displays certain distinguishing characteristics. ${ }^{34}$ This section of part I will attempt to identify these characteristics. In doing so, it is instructive to first examine how the Court has defined a "suspect" class.

In Massachusetts Board of Retirement $v$. Murgia, ${ }^{36}$ the Court described a suspect class as a "discrete and insular" " minority ${ }^{36}$ that has been " "saddled with such disabilities, or subjected to such a history of purposeful unequal treatment, or relegated to such a position of political powerlessness as to command extraordinary protection from the majoritarian political process.' "sz Suspect classifications include race and national origin. ${ }^{38}$ Under current equal protection doctrine, suspect classifications trigger strict equal protection review. ${ }^{39}$

In Frontiero v. Richardson, ${ }^{40}$ a 1973 decision, a plurality of the Court advocated treatment of gender as a suspect classification. ${ }^{41}$ A ma-

" "to reject the legislative judgment on the basis that without convincing statistics in the record to support it, the legislative viewpoint constitutes nothing more than . . . "pure speculation." ").

34 Scholarly commentary supports recognition of "sensitive" classifications that trigger intermediate scrutiny. Gunther asserts that "[e]fforts to expand the category of ... 'quasi-suspect' classification . . . is one of the strands of the 'new equal protection," G. GuNTHER, supra note 3 , at 862 , and argues that such classifications that have triggered heightened scrutiny have included "sex," "alienage," and "illegitimacy," id. at 862-63. Similarly, Tribe has argued that intermediate review can be triggered

if sensitive, although not necessarily suspect, criteria of classification are employed. Thus the Court has stressed the role of increasingly outdated stereotypes in the gender cases, and the place of a long history of disadvantageous treatment in the alienage and illegitimacy cases. Whether or not the groups in question might qualify for treatment as 'discrete and insular' minorities, they bear enough resemblance to such minorities to warrant more than a casual judicial response when they are injured by law.

L. TRIBE, supra, note $3 \S 16-31$ at 1090 (footnotes omitted).

ss 427 U.S. 307 (1976) (per curiam). n.4 (1938)).

${ }^{36} I d$. at 313 (quoting United States v. Carolene Products Co., 304 U.S. 144, 152

37427 U.S. at 313 (quoting San Antonio Indep. School Dist. v. Rodriguez, 411 U.S. 1,28 (1973)).

s8 See supra note 6.

s9 See, e.g., Murgia, 427 U.S. at 312; cf. Comment, Suspect Classifications: $A$ Suspect Analysis, 87 DICK. L. REv. 407, 427-34 (1983) (criticizing the Court's suspect class analysis for its lack of a cogent definition of "suspect class" and its focus on group rather than on individual rights to equality).

40411 U.S. 677 (1973).

12 Id. at $682-88$. The plurality opinion in Fronterio was written by Justice Bren- 
jority of the Court, however, has never endorsed this view. ${ }^{42}$ Instead, in 1976, the majority in Craig $v$. Boren, ${ }^{43}$ applied intermediate scrutiny to a gender classification without deciding whether gender was suspect or not. However, in holding that a gender classification must be substantially related to an important state interest, ${ }^{44}$ the Craig Court articulated a standard of review for a newly recognized kind of class. In effect, the Craig Court treated gender as a sensitive classification-not entitled to strict scrutiny as a suspect class would be, but entitled to a more exacting review than rationality scrutiny. Chief Justice Burger, dissenting in Craig, noted that "[ $t]$ hough today's decision does not go so far as to make gender-based classifications 'suspect,' it makes gender a disfavored classification." 45

While the Craig majority did not clearly articulate why it was applying a higher standard of review to gender classifications, ${ }^{46}$ several factors can be gleaned from the opinion. The Court implied that one reason for applying intermediate scrutiny was that gender classifications often reflect "'archaic and overbroad' generalizations." thus suggests that the Court will apply heightened scrutiny to a classification if it reflects inaccurate stereotypes that are not truly indicative of a group's abilities. ${ }^{48}$

nan and joined by Justices Douglas, White, and Marshall.

12 Justice Stewart concurred in the judgment without endorsing the treatment of gender as a suspect classification. See id. at 691. Chief Justice Burger and Justices Powell and Blackmun concurred in the judgment but considered it unnecessary "in this case to characterize sex as a suspect classification." Id. at 691-92. Justice Rehnquist dissented. See id. at 691.

43 U.S. 190 (1976).

4 Id. at 197-99.

15 Id. at 217 (Burger, C.J., dissenting) (emphasis added).

${ }^{18}$ See id. at 190. The Craig majority argued that the standard that it was applying had been established by precedent. The Craig standard derived primarily from Reed v. Reed, 404 U.S. 71 (1971). In Reed, the Court struck down a gender classification, relying on a rigorous version of the rationality standard from Royster Guano Co. v. Virginia, 253 U.S. 412, 415 (1920), which required that a classification have a "fair and substantial relation to the object of the legislation." Reed, 404 U.S. at 76. The Court in Craig did not apply the more deferential version of rationality scrutiny from McGowan v. Maryland, 366 U.S. 420 (1961), which stated that "[a] statutory discrimination will not be set aside if any state of facts reasonably may be conceived to justify it." Id. at 426 (citations and footnote omitted). In cases involving economic or social welfare, the Court often employs the McGowan version of rationality scrutiny rather than the Reed/Royster Guano "fair and substantial relation" test. See, e.g., Dandridge v. Williams, 397 U.S. 471, 485 (1970). Thus, the Craig majority's citation to Reed to justify its standard of equal protection scrutiny does not fully explain why it was applying a more exacting level of scrutiny to gender than the deferential McGowan "conceivable rational basis" test that it applies to many other classifications. (1975)).

${ }^{47}$ Craig, 429 U.S. at 198 (quoting Schlesinger. v. Ballard, 419 U.S. 498, 508

48429 U.S. at $198-99$. 
In addition, the majority decision in Craig can be reasonably explained as an unarticulated compromise between the old Frontiero plurality, who had wanted to treat gender as a suspect class, and the other justices, who were unwilling to go so far. The compromise appears to treat women as entitled to some heightened level of review because they were somewhat suspect. Under this approach, gender would be treated as a sensitive classification because women had been subjected to some discrimination-but not as much as a suspect class-and because they had suffered from a certain degree of political powerlessness-but not as severely as a suspect group..$^{49}$

Gender is not the only classification that will invoke intermediate level scrutiny. The Court's treatment of illegitimacy indicates that the Court will also consider a classification as sensitive if it is based on a personal characteristic over which an individual has no control. In several recent cases the Court struck down state statutes of limitations for paternity and child support suits brought on behalf of illegitimate children. ${ }^{\text {so }}$ In holding that a shorter time period for illegitimate children ${ }^{51}$ to bring suit was not substantially related to the legitimate state goal of preventing fraudulent claims, ${ }^{52}$ the Court was de facto treating the illegitimacy classification as sensitive. The Court justified its application of intermediate scrutiny to the classification by noting that punishing a group for a characteristic over which the group's members have no control is "illogical and unjust" " and "contrary to the basic concept of our system that legal burdens should bear some relationship to individual responsibility or wrongdoing." "53

This brief summary of the gender and illegitimacy cases demonstrates that the Court has relied upon at least three factors to indicate the presence of sensitive classes: (1) a group that has suffered from the same history of discriminatory treatment as a suspect class but in such a milder form that the class itself does not qualify as suspect; (2) a classification that reflects stereotypes that are archaic and overbroad or not truly indicative of abilities; and (3) a personal trait over which the individual has no control.

49 Cf. id. at 217-20 (Rehnquist, J., dissenting). Justice Rehnquist argued that the absence of a history or pattern of discrimination against men as a class militates against application of "any kind of special scrutiny." Id. at 219.

so Pickett v. Brown, 103 S. Ct. 2199 (1983); Mills v. Habluetzel, 456 U.S. 91 (1982). But see Lalli v. Lalli, 439 U.S. 259, 265 (1978) (Powell, J., plurality opinion).

${ }^{81}$ Under the applicable state laws, a legitimate child had the right to seek support from its natural father until the age of eighteen. See Mills v. Habluetzel, 456 U.S. 91, 100 N.7 (1982).

${ }^{32} I d$. at 101.

ss Pickett v. Brown, 103 S. Ct. 2199, 2204 (1983) (quoting Weber v. Aetna Casualty \& Sur. Co., 406 U.S. 164, 175-76 (1972)). 
In all of the above cases, the presence of the sensitive class was, by itself, sufficient to trigger intermediate scrutiny. In Plyler $v$. Doe, ${ }^{54}$ the Court first applied intermediate scrutiny in a situation that also implicated the other strand of equal protection: the fundamental interest. The next section discusses the effect Plyler may have on intermediate level scrutiny.

\section{B. Plyler v. Doe}

In Plyler v. Doe the Court applied intermediate equal protection scrutiny to strike down a Texas law that denied free public education to illegal alien children. ${ }^{.5}$ Two potential rationales are suggested by this result: either illegal aliens are a sensitive class or education, while not fundamental, ${ }^{B 6}$ is a type of important right that triggers intermediate scrutiny.

The Court's opinion, while not a model of clarity, does not seem to rely on either of these easily available routes. Rather, it suggests that a combination of the two strands of equal protection influenced the decision.

In part of the opinion, the Court applied the standard de facto sensitive class analysis. ${ }^{57}$ While conceding that illegal alien children do not constitute a suspect class, ${ }^{58}$ the majority nevertheless justified application of intermediate review by stressing that the challenged classification was analogous to illegitimacy classifications that had triggered intermediate scrutiny: the law penalized illegal alien children for their status, over which they had no control. ${ }^{69}$ Furthermore, the Court indicated that illegal aliens share many of the characteristics of a suspect class, but in a milder form. It argued that they constitute a "disfavored"60 "underclass" that is "virtually defenseless against ...

457 U.S. 202 (1982).

Bs Id. at $223-24,230$.

${ }^{86}$ Fundamental rights trigger strict scrutiny. See supra notes 7-8 and accompanying text. Only those rights explicitly or implicitly guaranteed by the Constitution are considered fundamental. Rodriguez v. San Antonio Indep. School Dist., 411 U.S. 1, 3334 (1973).

"7 Although the Plyler majority did not explicitly use the word "sensitive," it again de facto applied such an analysis. The dissenters sharply criticized the majority for employing a "quasi-suspect-class" rationale in order to justify application of an intermediate standard of review. See Plyler, 457 U.S. at 244 (Burger, G.J., dissenting).

so Id. at 223.

oo Id. at 220; see also id. at 238 (Powell, J., concurring). But see id. at 245 (Burger, C.J., dissenting) (arguing that "the Equal Protection Clause does not preclude legislators from classifying among persons on the basis of factors and characteristics over which individuals may be said to lack 'control" ").

co Id. at 222.

II. at 219. 
exploitation." "62

However, beyond this standard theory, the Plyler analysis of illegal alien children contains an important development in the de facto treatment of certain groups as sensitive. The Court innovated by treating the sensitive status of illegal alien children as insufficient by itself to justify application of intermediate scrutiny. Instead, it relied on a combination of four factors to justify intermediate scrutiny, and did not suggest that any combination of fewer elements could trigger such heightened review. The first two factors were based solely on the sensitive status of the class: (1) the statutory classification penalized innocents for a trait over which they had no control; ${ }^{63}$ and (2) it harmed the interest of a group that by virtue of its history of disfavored treatment, is analogous to a suspect class. ${ }^{64}$ This section has identified these factors as characteristics of a sensitive class.

The third factor stressed by the Plyler Court, however, was at least partially derived from the importance of the interest at stake. The Court was extremely concerned with the effect that the denial of the statutory interest involved would have on the already sensitive class. The Texas law in question tended to create a new, perhaps permanent, underclass; by denying education to these illegal alien children, a new subclass of illiterates was being created. ${ }^{65}$ The Court noted that "[p]aradoxically, by depriving the children of any disfavored group of an education, we foreclose the means by which that group might raise the level of esteem in which it is held by the majority."68 Thus, a third reason that the Court applied intermediate scrutiny was that the statute tended to transform an already sensitive group into a permanent underclass. $^{.7}$

The fourth factor that the Plyler Court emphasized was the importance of education and the devasting effect of its denial to children. ${ }^{\mathbf{6}}$ While noting that public education is not a right explicitly guaranteed by the Constitution, ${ }^{69}$ the Court felt that education had a "fundamental

${ }^{82}$ Id. at 219 n.18 (quoting Doe v. Plyler, 458 F. Supp. 569, 585 (E.D. Tex. 1978), affd, 457 U.S. 202 (1982)).

${ }_{63}$ See supra note 59 and accompanying text.

- See supra notes 60-62.

${ }^{65}$ Plyler, 457 U.S. at 230 ([T]he statute will "promot[e] the creation and perpetuation of a subclass of illiterates."); see also id. at 234 (Blackmun, J., concurring) ("[T]he Texas scheme inevitably will create 'a subclass of illiterate persons." ").

${ }^{68} I d$. at 222 (citations omitted).

67 Id. at 234 (Blackmun, J., concurring) ("Children denied an education are placed at a permanent and insurmountable competitive disadvantage, for an uneducated child is denied even the opportunity to achieve.").

${ }_{68}$ Id. at 221-24.

69 Id. at 221 (citing San Antonio Indep. School Dist. v. Rodriguez, 411 U.S. 1, 35 (1973)). 
role in maintaining the fabric of our society."70 If the sensitive status of illegal alien children had been sufficient to justify application of intermediate scrutiny, then the Court's lengthy discussion of the importance of education would not have been necessary. Thus, Plyler suggests that sometimes a combination of a sensitive classification and the denial of an important right is necessary to trigger intermediate scrutiny. ${ }^{\mathbf{7 1}}$

Although Plyler was admittedly based on a unique confluence of factors, ${ }^{72}$ the majority's reasons for treating education as an element helping to trigger intermediate scrutiny suggest other interests that fit the same description. It is therefore important to look at those justifications.

While the rationale of Plyler is murky, apparently one of the rea-

$20 \mathrm{Id}$. at 221.

${ }^{71}$ Cf. L. TRIBE, supra note $3, \S 16-31$, at $1090 \mathrm{n}$.10. Writing in 1978, considerably before Plyler, Tribe argued that the Court had applied intermediate scrutiny in cases that "combine[d] sensitive criteria of classification with important liberties." Id. Tribe cited three cases to support this contention: Hampton v. Mow Sun Wong, 426 U.S. 88 (1976); United States Dep't of Agriculture v. Moreno, 413 U.S. 528 (1973); and Stanley v. Illinois, 405 U.S. 645 (1972). See id. Tribe's analysis suggests that Plyler did not represent an innovation inasmuch as it applied intermediate scrutiny to a combination of the presence of a quasi-suspect classification and the denial of an important interest.

This Comment asserts, however, that Plyler is the first clear example of intermediate scrutiny being applied to such a combination. In Plyler the Court not only explicitly recognized the existence of the intermediate tier of review, but also explicitly applied it. See Plyler, 457 U.S. at 218 n.16.

In contrast, the Court purported to apply rationality scrutiny in both Mow Sun Wong, see 426 U.S. at 115-17, and Moreno, see 413 U.S. at 533-38. Even if the Court actually applied heightened scrutiny in these cases, the cases do not represent clear examples of intermediate review.

Stanley $v$. Illinois, the third case cited by Tribe, is a due process case that held that the statute was unconstitutional because the classification did not permit rebuttal. Requiring that rebuttal be permitted is a technique of intermediate review under Tribe's analysis, but it is not an element of intermediate review under this Comment's analysis. Thus, the disagreement between Tribe and this Comment regarding Stanley simply reflects differing views as to the appropriateness of including the "irrebutable presumption" doctrine in a definition of intermediate review.

72 See Plyler, 457 U.S. at 236 (Powell, J., concurring) (stressing the "unique character" of the case); id. at 243 (Burger, C.J., dissenting) ("[T]he Court's opinion rests on such a unique confluence of theories and rationales that it will likely stand for little beyond the results in these particular cases.").

The majority in Plyler also attempted to claim that education was a uniquely important interest. They argued that education is not "merely some governmental 'benefit' indistinguishable from other forms of social welfare legislation. Both the importance of education in maintaining our basic institutions, and the lasting impact of its deprivation on the life of the child, mark the distinction." Id. at 221.

The majority's rationale does not distinguish subsistence from education. Substance, even more than education, is essential to maintaining the basic institutions of our society. Such institutions would crumble if citizens were denied the bare means of survival. A denial of the means of subsistence can cause permanent physical and emotional damage. 
sons the Court felt that the denial of education should help trigger intermediate scrutiny was that education has a close nexus with the exercise of constitutional rights. To the extent this interpretation is correct, it means that Plyler may be inconsistent with the Supreme Court's holding in San Antonio Independent School District v. Rodriguez ${ }^{\mathbf{3}}$ and must be seen as implicitly overruling at least a part of it.

In Rodriguez the Court rejected an argument that education is so important and has such a close nexus with the effective exercise of first amendment rights that it ought to be treated as a fundamental right. ${ }^{74}$ The majority reasoned that treating interests as fundamental simply because of their social or economic importance would improperly lead to the creation of substantive constitutional rights in the name of equal protection. ${ }^{75}$ The Court held that whether an interest is fundamental is not determined by its societal importance; a right is fundamental only if it is explicitly or implicitly guaranteed by the Constitution. ${ }^{76}$

Furthermore, the Rodriguez Court noted that the plaintiff's "nexus" argument with respect to education went too far since it would lead to what the Court considered the reductio ad absurdum of heightened equal protection scrutiny of laws trenching on enterests in welfare benefits and housing. Since statistics probably could be produced to demonstrate that a deprivation of welfare or housing significantly dampens the exercise of constitutional rights, a nexus analysis would require the Court to treat these interests as fundamental. ${ }^{77}$ Such a result, noted the Court, would be contrary to its decisions in Dandridge v. Williams ${ }^{78}$ and Lindsey v. Normet, ${ }^{79}$ in which the Court held that welfare and housing were not fundamental interests. ${ }^{80}$

When Rodriguez was decided in 1973, the Court still assumed a dichotomous equal protection universe in which the only levels of review that could be applied were strict or rationality scrutiny. ${ }^{81}$ The intermediate standard of equal protection review was not yet fully developed. ${ }^{82}$ Thus, since a nexus with constitutional rights was not sufficient to make an interest fundamental and trigger strict scrutiny, the Court held that rationality scrutiny must be applied. ${ }^{83}$

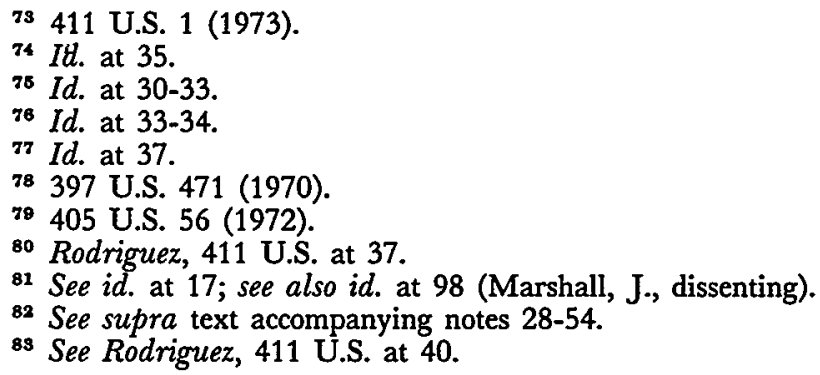


The dichotomous Rodriguez formulation fails to recognize how closely interests such as education and subsistence are connected with constitutional rights. A law that interferes with these interests may discourage the exercise of constitutional rights even more than a law that encroaches directly on what the Rodriguez Court would consider a fundamental right. ${ }^{84}$

The majority in Plyler seemed implicitly to recognize this reality. They noted the importance of education "to participation in core political institutions" self-sufficient participants in society." "88 This reasoning is almost indistinguishable from the argument made by the plaintiffs in Rodriguez, who contended that the first amendment's " 'marketplace of ideas' is an empty forum for those lacking basic communicative tools"87 and that our present democratic electoral process depended upon an intelligent and "informed electorate."

In Plyler, the Court held that education is so important to the exercise of certain fundamental rights that its denial to illegal alien children could help trigger intermediate scrutiny. Inasmuch as the Court was actually adopting a nexus argument without so naming it, Plyler overruled sub silentio the rigid Rodriguez doctrine that relegated interests with mere nexus to rationality scrutiny. ${ }^{89}$

This Comment argues that Plyler should be interpreted to stand for the proposition that denial of an interest that is very important and that has a very close nexus with the exercise of constitutional rights can help trigger intermediate scrutiny. ${ }^{90}$ By so interpreting $P l y l e r$, the scope of strict scrutiny could still be sharply restrained, ${ }^{91}$ while providing a

84 Justice Marshall, dissenting in Rodriguez, pointed out this flaw by stating that "[o]nly if we closely protect the related interests from state discrimination do we ultimately ensure the integrity of the constitutional guarantee itself." Id. at 103 (Marshall, J., dissenting).

${ }^{8 s}$ Plyler, 457 U.S. at 221 n.20.

${ }^{86}$ Id. at 222 (quoting Wisconsin v. Yoder, 406 U.S. 205, 221 (1972)).

${ }^{87}$ Rodriguez, 411 U.S. at 35.

88 Id. at 36.

80 Rodriguez did not involve an absolute deprivation of education. The challenged Texas scheme was a financing system that relied upon local property taxes. The plaintiffs contended that this system unfairly favored the students who lived in the more affluent parts of the state. See id. at 1. It might be argued that the issue of how a complete denial of an interest with a constitutional nexus should be treated was left open in Rodriguez (and answered in Plyler). Justice Blackmun, in a concurring opinion, explicitly noted that he felt Plyler left Rodriguez intact for this reason. See Plyler, 457 U.S. at 234-35.

20 See supra note 72. Plyler may involve such a unique combination of elements triggering intermediate scrutiny that its application is precluded beyonds its specific facts.

91 Strict scrutiny would still be limited to suspect classifications and denials of 
first line of defense for constitutional rights by applying intermediate scrutiny to infringements of related interests. Furthermore, such an interpretation of Plyler would lessen the problem of distinguishing between rights implicitly guaranteed by the Constitution and those with a close nexus because the result of the choice would be less drastic. A judge could choose between applying strict or intermediate scrutiny, rather than be forced into an all-or-nothing choice between strict scrutiny and deferential rationality scrutiny.

\section{Application of Plyler $v$. Doe to Welfare Laws}

The theory derived from Plyler v. Doe ${ }^{92}$ can be used to apply heightened scrutiny to laws that would receive only minimal scrutiny under Dandridge $v$. Williams. ${ }^{93}$ Subsistence, like education, should be recognized by the courts as an important right whose denial to a sensitive class triggers intermediate scrutiny. This suggestion, in apparent conflict with the broad language of Dandridge, is in fact consistent with the results of Dandridge and its progeny.

Section A of this part will examine the concept of subsistence in more detail to show that it, like education, should be accorded important right status. Section B will demonstrate that this conclusion will not contravene the precedent set by Dandridge.

\section{A. The Constitutional Importance of Subsistence}

"Subsistence" denotes the bare means of survival-the food, shelter, clothing, and medical care necessary to maintain life. This definition does not require that a needy person first die to be considered as being deprived of subsistence. Subsistence is denied when the destitute person is provided with such a low level of assistance (or no assistance at all) that she would be incapable over the long run of keeping body and soul together.

As defined by this Comment, subsistence does not include the means necessary for a comfortable or decent lifestyle, but rather is limited solely to the bar means necessary for survival. Furthermore, a total denial of one type of welfare does not necessarily constitute a denial of subsistence because the recipient may be eligible for other assistance (or may have alternative sources of income) and thus is not being deprived of the means of staying alive. ${ }^{94}$

fundamental rights.

${ }_{92} 457$ U.S. 202 (1982).

os 397 U.S. 471 (1970).

or Admittedly, this makes the determination whether a particular law denies sub- 
Since subsistence is not guaranteed by the Constitution, it is not fundamental, and its infringement does not trigger strict scrutiny. ${ }^{95}$ Nonetheless, subsistence like education, is so important to the exercise of constitutional rights that its denial to a sensitive group should trigger intermediate equal protection scrutiny. As the court noted in Goldberg $v$. Kelly, ${ }^{96}$ termination of welfare benefits that forces an indigent into a desperate struggle for survival renders that person practically incapable of protecting her rights. ${ }^{97}$

It is not asserted here that a citizen has an affirmative constitutional right to welfare, nor that the denial of subsistence by itself should trigger heightened scrutiny. A state could deny welfare to all its citizens without raising equal protection concerns. Rather, this Comment is particularly concerned with laws that discriminatorily deny to certain disadvantaged groups the basic means of survival. The definition employed herein of the traits characterizing a sensitive group is an attempt to identify those factors that should warn a court that denial of subsistence to a particular group is probably motivated by prejudice ${ }^{88}$ and is therefore so problematic under the equal protection clause as to require scrutiny more demanding than that required under rationality review.

In one drastic sense, subsistence is a necessary prerequisite to the exercise of all constitutional rights because the deprivation of subsistence for too long results in death. However, even when a denial of

sistence problematic. Since subsistence depends on a person's other available resources, it may be that a law that cuts off one source of welfare denies subsistence to some, but not to others. However, this possibility by itself should not dissuade a court from determining that the law in question denies subsistence. That the legislative classification in question is broad enough to encompass also some who have other means of support does not make it any more legitimate. Not all members of sensitive groups are in the same stages of financial need; however, if it appears that a substantial percentage of those the law affects are being denied subsistence, this should be sufficient for a court to find that the law denies subsistence. (1973).

9s See San Antonio Indep. School Dist. v. Rodriguez, 411 U.S. 1, $32-34$ \& n.72

96397 U.S. 254 (1970).

97 Id. at 264.

98 See Blattner, The Supreme Court's "Intermediate" Equal Protection Decisions: Five Imperfect Models of Constitutional Equality, 8 Hastings Const. L.Q. 777, 80408 (1981). Although in many cases the denial of subsistence may be claimed to have been motivated by a desire to cut expenses, under the intermediate standard of review an interest in reducing government expenses is by itself insufficient to qualify as an "important" or "substantial" state interest. See Plyler, 457 U.S. at 227 ("[A] concern for the preservation of resources standing alone can hardly justify the classification used in allocating those resources." (citation omitted)); see also id. at 249 (Burger, C.J., dissenting); $c f$. Craig v. Boren, 429 U.S. 190, 198 (1976) ("Decisions following Reed similarly have rejected administrative ease and convenience as sufficiently important objectives to justify gender-based classifications." (citations omitted)). 
subsistence "merely" results in an indigent being unable to pay for food or rent and forces her to try to survive as a "street person,"99 constitutional rights can also be infringed.

The right to participate in state elections on an equal basis, once the state grants the franchise, is a constitutional right conferred by the equal protection clause. ${ }^{100}$ This right is indirectly infringed upon by a denial of subsistence, which can uproot a person from her residence if she cannot pay her rent. Without a residence, an indigent is foreclosed from registering to vote and thus loses the opportunity to participate in our political system.

Similarly, a denial of subsistence interferes with the first amendment rights of free speech, assembly, and petition. People forced to engage in a desperate hand-to-mouth existence are relegated to margins of society, without the resources or energy to communicate effectively with other citizens or the government. In addition, the deprivation of subsistence interferes with the constitutional right to interstate travel recognized in Shapiro $v$. Thompson. ${ }^{101}$ The freedom to travel implies the freedom to remain. Yet a denial of subsistence in one state puts strong pressure on the poor to travel to another state to obtain the necessities of life. ${ }^{102}$

s9 See Price v. Cohen, 715 F.2d 87, 90-91 (3d Cir. 1983) (discussing plight of named plaintiffs who would probably be forced to try to survive on the street); see also infra text accompanying notes 147-53 (discussing affidavits in Price describing how many destitute persons have been forced into the streets by the termination of welfare benefits).

${ }^{100}$ Harris v. McRae, 448 U.S. 297, 322 n. 25 (1980); Dunn v. Blumstein, 405 U.S. 330,336 (1972).

101 Shapiro v. Thompson, 394 U.S. 618, 629-31 (1969).

102 Common sense would indicate that the denial of subsistence interferes with the constitutional right of privacy recognized in Roe v. Wade, 410 U.S. 113 (1973). If a person is struggling just to keep herself alive, her freedom to make personal choices regarding marriage, raising children, or abortion is severely circumscribed. $C f$. id. at 152-53 (discussing scope of constitutional right of privacy).

The Court has twice held, however, that the constitutional right to freedom to make certain private choices does not carry with it a constitutional entitlement to be provided with funds to remove an obstacle to freedom of choice caused by poverty. See Harris v. McRae, 448 U.S. 297, 316 (1980); Maher v. Roe, 432 U.S. 464, 473-75 (1977). In these two cases, the Court held that an indigent woman's constitutional right of privacy is not violated by a denial of welfare-funded abortions.

The Court's rationale in Harris v. McRae and Maher v. Roe implied that many individual constitutional rights are defined negatively as rights to be free from government interference with a protected activity, rather than defined positively as guarantees creating affirmative government obligations to provide the needy with the means necessary to engage in the guaranteed activity. See McRae, 448 U.S. at 313-18; Maher, 432 U.S. at 473-77.

If all individual constitutional rights are defined solely in negative terms as the right to be free from government interference with protected activities, and if government denial of the means to engage in an activity to a destitute person who would not otherwise have the means to engage in it is not government interference, then denial of 
Subsistence is relevant in another way. The denial of education in Plyler was problematic because it tended to create a permanent underclass of illiterates. ${ }^{103}$ Similarly, the denial of subsistence tends to transform what may be a temporary state of need into a permanent one. A person depending on public assistance is still capable of being a productive member of society. Forcing that person out into the street almost guarantees the elimination of any productive potential. With no permanent address and no resources, the chances of a "street person" finding employment are almost nonexistent, particularly when her day-to-day existence is caught up in merely trying to survive. ${ }^{104}$ Such indigents, even more than those receiving welfare, should be treated as a disfavored class in society.

Thus, the denial of subsistence is very similar to the denial of edu-

subsistence would never infringe on any constitutional right.

Even Maher and related cases, however, recognize that certain rights impose an affirmative obligation on the government. Where the government has a monopoly over a protected activity, see id. at 469 n.5, or compels participation in that activity, see id. at 471 n.6, it has an affirmative obligation to provide the means of access to participate in that activity. Thus in Boddie v. Connecticut, 401 U.S. 371 (1971), the Court held that the state must provide indigents access to the legal means for obtaining a divorce, an activity over which the state exercised a monopoly. See id. at 380-81; cf. United States v. Kras, 409 U.S. 434 (1973) (state can constitutionally require an indigent to pay a court fee in order to obtain discharge in bankruptcy because discharge in bankruptcy was not only way in which a debtor could obtain relief from his creditors).

Since the franchise is subject to a government monopoly, Maher and related cases suggest that the right to vote imposes an affirmative obligation on the government to provide the means of access to the ballot and further suggest that this right can be infringed upon by a denial to the poor of the means of access. Thus a denial of subsistence that indirectly forecloses participation in the ballot could infringe upon this right.

Indeed, the "government monopoly" exception to the Maher rule that rights are negatively defined highlights the problems with the rule. If logically applied, the exception would swallow the rule. Any time a person is so indigent that she cannot afford to participate in a protected activity without government aid, the government effectively has a monopoly over that indigent person's participation in that right. This creates-under the government monopoly exception-an affirmative obligation on the part of the state to provide the means of access to that activity.

In summary, even under a theory of constitutional rights that views such rights as defined solely in negative terms except where the government has a monopoly on the exercise of the right, the denial of subsistence interferes with the affirmative right to participate on an equal basis in state elections (a government monopolized activity). Thus subsistence has a nexus with constitutional rights, even if they are narrowly defined. However, since such a strictly negative view of constitutional rights has not been consistently applied (see, e.g., Plyler and Shapiro) and since its application would have serious theoretical flaws, the Maher rule should not be construed as covering more than the right to privacy. If constitutional rights other than an interest in subsistence are defined in terms that are not solely negative, then the denial of subsistence would also interfere indirectly with the right to interstate travel, and the exercise of the first amendment rights of free speech, petition, and assembly.

${ }^{103}$ See supra notes 65-67 and accompanying text.

104 For a more extensive view of the bleak prospects facing a person living in the street, see infra text accompanying notes 147-54. 
cation in two important ways: it indirectly infringes upon the exercise of constitutional rights, and it tends to create a permanent underclass. From Plyler, it follows that the denial of subsistence should be considered a factor that helps trigger intermediate scrutiny.

The range of "important" interests-those interests the deprivation of which aid in invoking intermediate scrutiny- should be narrowly construed. The importance of an interest is relevant for equal protection analysis in only two ways. First, the importance of an interest with a nexus with constitutional rights is relevant only to the extent a deprivation of this related interest would result in a serious indirect infringement of constitutional rights. In this respect, the societal importance of an interest that has no nexus with constitutional rights is not relevant to equal protection analysis. ${ }^{105}$

The interest must be extremely important to the exercise of constitutional rights in order for its denial to trigger intermediate scrutiny. The Court in Plyler emphasized that education is of " supreme importance." "106 Only denials of interests of paramount importance, such as education and subsistence, that are necessary prerequisites for the exercise of constitutional rights should help trigger intermediate scrutiny.

Second, the importance of in interest is relevant to equal protection analysis insofar as the denial of an important tool of self-help to a sensitive group can create a permanent underclass. This argument derives support from the Plyler rationale that denial of education to a discrete class of children creates an "obstacle . . . to individual achievement"107 and thus "poses an affront to one of the goals of the Equal Protection Clause: the abolition of governmental barriers presenting unreasonable obstacles to advancement on the basis of individual merit."108 In Plyler the Court was concerned with this aspect of importance when it stressed that " it is doubtful that any child may reasonably be expected to succeed in life if he is denied the opportunity of an education." "100

Of course, the denial of any socially or economically important interest to a group tends to lower that group's status in the community, thereby creating an underclass. If the opportunity for advancement on

105 Tribe apparently believes that the deprivation of any socially or economically important interest, such as an interest in retaining a driver's license or obtaining higher education at an affordable tuition, should trigger intermediate review. See L. TRIBE, supra note $3, \S 16-31$; at 1090 . His view is arguably supported by Plyler $v$. Doe. In Plyler, the Court helped justify intermediate scrutiny of a deprivation of education by observing that education was important for an individual's cultural and social development, as well as her economic advancement. See Plyler, 457 U.S. at 221-23.

${ }_{106} 457$ U.S. at 221 (quoting Meyer v. Nebraska, 262 U.S. 390, 400 (1923)).

107 Id. at 222.

108 Id. at 221-22.

${ }^{109}$ Id. at 223 (quoting Brown v. Board of Educ., 347 U.S. 483, 493 (1954)). 
the basis of personal merit remains open, however, members of the disfavored group have a chance to improve their position. In contrast, the denial of the tools for self-help has a much stronger tendency to create a society divided by caste since it not only "creat[es]" but also "perpetuat[es] . . . a sub-class"110 by precluding members of the affected group from improving their position through their own effort.

Thus, under the approach outlined here, the importance of an interest is only relevant to equal protection analysis in two narrow aspects that are clearly tied to constitutional norms. ${ }^{111}$

\section{B. Reconciling Dandridge v. Williams}

Dandridge $v$. Williams ${ }^{112}$ presents a major obstacle to the approach outlined above because the Supreme Court in that case seemed to indicate that rationality scrutiny is to be applied to all welfare laws. ${ }^{113}$ However, Dandridge can, in a manner consistent with the development of intermediate equal protection review, be interpreted to permit intermediate scrutiny of public assistance laws that deprive a sensitive group of subsistence.

In Dandridge and its progeny, the Court has never actually applied deferential rationality scrutiny to a law that denied subsistence. It has only applied the conceivable rational basis test in cases where the termination or reduction in welfare did not threaten an interest in survival.

For example, Dandridge itself involved an equal protection challenge to a Maryland welfare statute that imposed a maximum limit on

110457 U.S. at 230 .

111 This narrow interpretation of the range of important interests whose deprivation can help trigger intermediate scrutiny has significant advantages over a broader interpretation. See supra note 105. Tribe's view that denial of a socially or economically important interest should trigger intermediate scrutiny creates the danger of widespread judicial intervention unguided by constitutional norms. Almost any interest can be viewed by someone as important. See San Antonio Indep. School Dist. v. Rodriguez, 411 U.S. 1, 31 (1973) ("Virtually every"state statute affects important rights." ").

The Constitution provides no guidance as to what interests are socially or economically important. Thus, Tribe's view would set judges loose upon legislative enactments, armed with a relatively powerful weapon of judicial review, yet unguided (and unrestrained) by clear constitutional values. $C f$. J. ELY, DEMOCRACY AND DISTRUST (1980). Ely would argue that this Comment's approach is a form of "interpretivism" that tries to limit judicial review to protecting values discoverable within the terms of the written Constitution, and that Tribe's approach is a variant of "noninterpretivism" that enforces norms that cannot be discovered within the Constitution. Ely contends that both approaches are ultimately unworkable and that judicial review should be used to facilitate the representation of minorities when necessary to correct the malfunctioning of the majoritarian political process due to prejudice.

112397 U.S. 471,485 (1970).

118 Id. at 485 . 
Aid to Families with Dependent Children (AFDC) payments to families so that families with more than six members received the same flat grant, regardless of the number of additional children. ${ }^{114}$ Although this statute operated to reduce the AFDC payment per child in large families, ${ }^{115}$ it did not deny subsistence (that is, the bare means of survival) to these children. Dandridge upheld the challenged law on the grounds that it was rational. ${ }^{116}$ Similarly, in Richardson $v$. Belcher, ${ }^{117}$ the Court applied the rationality standard to uphold a statutory provision that reduced social security benefits to offset workmen's compensation. And, in Jefferson $v$. Hackney, ${ }^{118}$ the Court applied deferential rationality scrutiny in rejecting an equal protection challenge to a Texas law that provided lower grants to AFDG recipients than to the aged who received categorical assistance under the Social Security Act. ${ }^{110}$

In each of these cases the Court applied rationality scrutiny to laws that reduced welfare benefits without threatening an interest in subsistence. The results in these cases are thus not inconsistent with an application of intermediate scrutiny to certain denials of subsistence.

The Court has been more reluctant to apply rationality scrutiny to complete eliminations of welfare. An example of this wariness is Schweiker $v$. Wilson, ${ }^{120}$ which involved a due process challenge ${ }^{121}$ to a federal statute that totally denied certain Social Security Income benefits ( $\$ 25$ per month "comfort allowances") to patients institutionalized in public mental hospitals that did not receive Medicaid funds for the

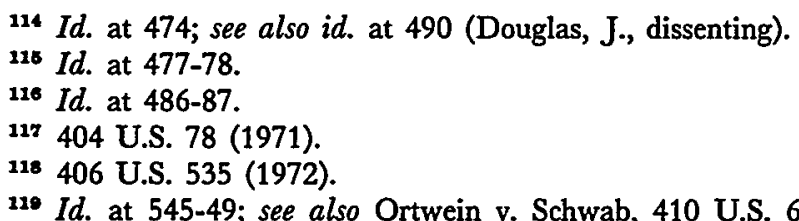

119 Id. at 545-49; see also Ortwein v. Schwab, 410 U.S. 656 (1973) (applying rationality standard of equal protection scrutiny to uphold Oregon law requiring $\$ 25$ appellate court filing fee; filing fee requirement had been challenged by plaintiffs seeking judicial review of agency determinations that had reduced their welfare benefits). In Harris v. McRae, 448 U.S. 297 (1980), the Court applied rationality scrutiny to a statute, the Hyde Amendment, that denied Medicaid funds to poor women for medically necessary abortions. Even this case did not involve a denial of the means of survival; under the Hyde Amendment, funds are denied for medically necessary abortions "except where the life of the mother would be endangered if the fetus were carried to term ...."Id. at 302.

190450 U.S. 221 (1981).

121 The plaintiffs attacked the "statutory classification as violative of the equal protection component of the Fifth Amendment's Due Process Clause." Id. at 226. The Court in Schweiker noted that it "repeatedly has held that the Fifth Amendment imposes on the Federal Government the same standard required of state legislation by the Equal Protection Clause of the Fourteenth Amendment." Id. at 226 n.6 (citing Weinberger v. Salfi, 422 U.S. 749, 768-70 (1975) and Richardson v. Belcher, 404 U.S. 78, 81 (1971)). 
patient's care. ${ }^{122}$ Although the majority applied rationality scrutiny, ${ }^{123}$ the opinion explicitly noted that "[f]or these people most subsistence needs are met by the institution and full benefits are not needed."124

Three other post-Dandridge cases also suggest that the Court is reluctant to apply Dandridge's deferential rationality scrutiny to laws that approach a denial of subsistence. In these cases, United States Department of Agriculture v. Moreno, ${ }^{125}$ United States Department of Agriculture $v$. Murry, ${ }^{126}$ and Wohlgemuth $v$. Williams, ${ }^{127}$ the Supreme Court purported to apply rationality scrutiny to laws that totally terminated welfare. ${ }^{128}$ In each case, however, the Court found the law to be irrational and invalidated it as unconstitutional. ${ }^{129}$ Given that each of these laws had a conceivable rational basis ${ }^{130}$ and that rationality scrutiny ordinarily creates a strong presumption that the challenged law is constitutional, ${ }^{131}$ the results in these cases indicate that the Court was not actually applying the extremely deferential rationality scrutiny called for by Dandridge, but rather was applying some form of slightly

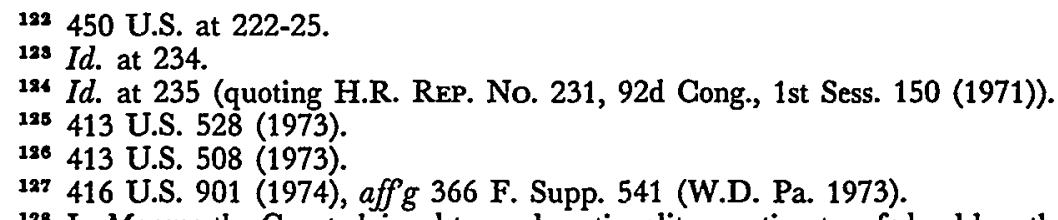

128 In Moreno the Court claimed to apply rationality scrutiny to a federal law that denied food stamps to any household that contained a member not related to other members of the household. In Murry the Court purported to apply a rationality standard of review to a federal law that denied food stamps to any household that contained a member over 18 years old who was claimed as a dependent child on his parent's federal income tax return. In Wohlgemuth the Supreme Court summarily affirmed a lower court's application of rationality scrutiny to a Pennsylvania regulation that denied general assistance to unemancipated minors living with an unrelated person, if the unrelated person did not receive assistance.

${ }_{120}$ Moreno, 413 U.S. at 538; Wohlgemuth, 366 F. Supp. at 549. In Murry, the Court stated that "[w]e have difficulty in concluding that [the challenged statute] is rational" and then held that, even assuming arguendo the law was rational, it would fail under the irrebutable presumption doctrine. Murry, 413 U.S. at 514.

${ }_{1 s 0}$ See Murry, 413 U.S. at 526 (Rehnquist, J., dissenting) (arguing that law was rational because parent who claimed child over 18 as dependent could and should support this older child rather than let him become a public charge); Moreno, 413 U.S. at 545-46 (Rehnquist, J., dissenting) (arguing that law should be upheld because Congress could rationally have believed that households of related persons live together for some other purpose than obtaining food stamps).

The challenged regulation in Wohlgemuth denied public assistance to unemancipated minors living with an unrelated adult who was not receiving aid. Wohlgemuth, $366 \mathrm{~F}$. Supp. at 545 . The regulation had a conceivable rational basis inasmuch as the welfare department rationally could have believed that the regulation would force an unrelated person, who was not on welfare and who had the means to provide for the minor, to support the child. To the extent the regulation encouraged a minor to live with her parents, it rationally served the goal of family cohesiveness.

131 See L. TRIBE, supra note 3, §§ 116-2 to 16-3, at 995-96; see also G. GuNTHER, supra note 3 , at $696-704$. 
heightened scrutiny. ${ }^{132}$

These three cases suggest that the Court would apply a higherthan-rationality level of scrutiny to a denial of subsistence. None of the cases involved a clear-cut refusal to supply subsistence (since the plaintiffs may have been eligible for more than one form of welfare benefits); it is difficult to believe that the Court would apply a less stringent standard of review where such subsistence was clearly in jeopardy. A far more likely possibility is that some form of intermediate-level review would be applied.

Dandridge and its progeny indicate that the Court has only applied rationality scrutiny to uphold welfare laws that do not threaten an interest in subsistence. The results of Murry, Moreno, and Wohlgemuth suggest that the Court actually tends to apply a more exacting standard of review to a total cut-off of welfare that approaches a denial of subsistence. Thus, intermediate scrutiny can be applied to welfare laws denying subsistence to sensitive classes without violating the precedent set by Dandridge.

\section{Application of Intermediate Scrutiny to Price v. Cohen}

The application of intermediate scrutiny is not only theoretically sound, but can also make a practical difference in the outcome of a case. To illustrate this, part III will re-examine the facts of Price $v$. Cohen. ${ }^{133}$

As was shown earlier, in Price the Court of Appeals for the Third Circuit reluctantly applied rationality scrutiny to a Pennsylvania welfare law that terminated welfare for thousands of general assistance recipients, upholding the law on the grounds that it had a conceivable rational basis. ${ }^{134}$ The challenged statute classified recipients as either "chronically" or "transitionally" needy. The transitionally needy were defined as those between eighteen and forty-five years old who did not fit into certain exceptions, while the chronically needy were defined as those over forty-five and those under forty-five who fit into certain categories. Thus, the primary classification was an age classification. ${ }^{\mathbf{1 3 5}}$

132 See Medora v. Colautti, 602 F.2d 1149, 1154 \& n.11 (3d Gir. 1979) (arguing that the Court applied "heightened scrutiny" in Murry and Moreno); G. GUNTHER, supra note 3, at 693-94 (listing Moreno as one of several "exercises of apparently heightened scrutiny despite avowals of mere rationality standards"); L. TRIBE, supra note $3, \S 16-55$, at 1127-28 \& n.1 (asserting that in Murry and Moreno the Court "demanded somewhat more in the way of governmental justification and fairness than would be required under the traditionally toothless minimum rationality test").

133 715 F.2d 87 (3d Cir. 1983).

1s. See supra notes 13-23 and accompanying text.

${ }^{135}$ Price, 715 F.2d at $89-90$. 
Whereas the chronically needy were entitled to year-round public assistance, the transitionally needy were eligible for only three months of public assistance a year. ${ }^{138}$

Under this Comment's proposal, intermediate equal protection scrutiny should be applied to welfare laws in which the statutory classification (1) denies subsistence (2) to a sensitive class. Since the law cuts off the transitionally needy from welfare after three months and since there are no adequate alternate sources of public or private assistance, the statute has a subsistence-threatening effect. ${ }^{137}$ Thus the first criterion is satisfied. The second criterion is also fulfilled; the statutory classification is sensitive because it is based on an inaccurate stereotype that younger welfare recipients can find work more easily than older recipients and thus are less deserving of welfare. ${ }^{138}$ Furthermore, the statutory classification tends to create an underclass by denying the transitionally needy the most basic tools of self-help.

Underlying the statutory classification of the transitionally needy as those recipients under forty-five years old who do not fit into certain exceptions is a legislative assumption that younger welfare recipients can more easily find jobs if they so desired. Although this might be true of the general population, no statistical correlation between age and employability was adduced in support of the Pennsylvania statute. The classification embodies a prejudicial and conclusory stereotype of "lazy" younger welfare recipients.

The court in Price stated that "the plaintiffs presented the essentially uncontroverted testimony . . . that the potential employability of persons who qualified for general assistance was unrelated to age."1s9 Two highly qualified labor specialists, with particular expertise in employment problems of the poor, ${ }^{140}$ had testified before the trial court that although there is a positive correlation between youth and employability among the general population, there is absolutely no correlation between age and employability among the welfare population. ${ }^{\mathbf{1 4 1}}$

136 Id. at 89.

137 See supra text accompanying notes 19-22; see also Price, 715 F.2d at 90-91.

138 This conclusion is consistent with the Supreme Court's determination that the deferential rational relationship test must be applied to age classifications. See Vance v. Bradley, 440 U.S. 93 (1979); Massachusetts Bd. of Retirement v. Murgia, 427 U.S. 307 (1976). The transitionally needy classification involves much more than an age classification; it embodies traditional stereotypes about the characteristics of people who receive public assistance.

${ }^{130}$ Price, 715 F.2d at 95.

140 See Appendix, supra note 21, at 55a; see also Appeal from the Order of the United States District Court for the Eastern District of Pennsylvania, Supplemental Appendix, at 231a-232a, Price v. Cohen, 715 F.2d 87 (3d Cir. 1983) [hereinafter cited as Supplemental Appendix].

${ }^{111}$ Appendix, supra note 21, at 40a-42a; Supplemental Appendix, supra note 
Welfare recipients, who tend to have low levels of education and job skills, tend to be eligible for only very low-level jobs that require little training. ${ }^{142}$ Since employers must provide little training in such jobs, they have less of an investment in the employee. Employers have less incentive to discriminate against older job applicants who have fewer employable years ahead of them. In contrast, the general population, by virtue of its higher level of education and job skills, is eligible for higher-level jobs with significant training costs that give an incentive for employers to discriminate against older job applicants. ${ }^{143}$ Thus, once the focus is upon individuals lacking education and job skills, age does not affect the chances of finding a job. ${ }^{144}$

Testimony presented by the state in Price in support of the age classification was extremely weak. The principal witness who spoke in behalf of the classification was an expert in the biological aging of fruit flies, who conceded that he was not a labor expert. ${ }^{145} \mathrm{He}$ further conceded that the statistics he presented showing a correlation between age and employability were based on the general population, not the welfare population. ${ }^{140}$

In addition, the statute tends to create an underclass by denying the transitionally needy the most essential tools of self-help. An affidavit by Daniel Stone, Executive Director of Adult and Family Services in the Philadelphia Department of Public Welfare, illustrates this effect of the statute. ${ }^{147}$ Stone testified that the city of Philadelphia provides shelter only for a period of five days to two weeks to those who have been terminated from state general assistance. After that, "the individual must leave." Furthermore, Stone asserted, "Our experience demonstrates that these individuals then become residents of the streets, abandoned cars, abandoned buildings, and the parks."148

A person forced to live in the street, with no source of income but begging or picking from garbage cans, is effectively foreclosed from improving his position through self-effort. Such severe destitution prevents a person keeping his clothes or body clean and thus makes finding employment extremely unlikely since she would be unpresentable at a job

140 , at $233 a-234 a$.

142 Supplemental Appendix, supra note 140, at 239a-241a.

148 Id. at 237a-239a.

14 Id. at $241 \mathrm{a}$.

${ }^{145}$ Id. at 265a-266a; see also Price v. Cohen, 565 F. Supp. 657, 660 (E.D. Pa.), rev'd, 715 F.2d 87 (3d Gir. 1983).

146 Supplemental Appendix, supra note 140, at 289a. See also Price v. Cohen, 565

F. Supp. 657, 660 (E.D. Pa.), rev'd 715 F.2d 87 (3d Cir. 1983).

147 Appendix, supra note 21, at 113a-117a.

148 Id. at 113a-114a. 
interview. Hunger and depression resulting from this deprivation could also seriously impede a job search.

Even during the indigents' short stay at municipal shelters, their extreme poverty presents an almost insuperable barrier to improving their position by finding a job. Stone testified that "shelter residents . . . very much want to work" but that they are provided with no financial assistance to buy "items for personal care [such as] soap, razors [or] kotex. . . . [W]ithout these items, [The residents] are unpresentable for job interviews."148 Furthermore, Stone testified that sheltered indigents lack "funds to look for employment" and "do not have money to make telephone calls or to take [public transportation] to job interviews."1so

Affidavits from private hospices presented an equally bleak picture. The hospices cannot possibly meet the huge demand created by the cutoff of the transitionally needy and are forced to make destitute men, women, and children leave after two or three weeks. ${ }^{151}$ According to these affidavits, many of these so-called transitionally needy "now live in the street, parks and in graveyards," or else in abandoned cars or houses. ${ }^{152}$ "[O]nce people get 'on the street' they develop physical and emotional problems which make them much more difficult to rehabilitate."15s

The overall picture that emerges is one of brutal deprivation that effectively renders the transitionally needy incapable of improving their position through their own effort. The statute creates an underclass by denying people the most fundamental tools of self-help. ${ }^{154}$

140 Id. at $115 \mathrm{a}-116 \mathrm{a}$.

180 Id.

181 Id. at $118 \mathrm{a}-126 \mathrm{a}$.

182 Id. at $119 \mathrm{a}$; see also id. at $123 \mathrm{a}$.

108 Id. at $125 \mathrm{a}-126 \mathrm{a}$.

184 Whether the transitionally needy display the other two characteristics which can identify a sensitive class is more debatable. It is not clear that the transitionally needy are being penalized for at trait over which they have no control. On the one hand, the transitionally needy have no control over the general high unemployment rate. Also, they are not responsible for their age, and the primary distinction between the chronically and transitionally needy is based on age. On the other hand, one reason that welfare recipients tend to be unemployable is their low level of education and work experience, for which they have some responsibility. When their job prospects are harmed by long histories of drug addiction or criminal convictions, individual responsibility is even greater.

Nor is it clear that the transitionally needy qualify as sensitive by virtue of displaying the traits of a suspect group but in milder form. Since the transitionally needy classification is a legislative innovation, the group has not suffered from any history of purposeful unequal treatment directed against them as a discrete class.

On the other hand, the challenged statute constitutes a serious legislative setback for the transitionally needy, indicating that they are politically powerless. In any event, the statute results in such serious deprivation to the transitionally needy that it creates a 
Since the transitionally needy display one or more of the traits that identify a sensitive group, they constitute a sensitive classification. In these circumstances, where subsistence is being denied to a sensitive class, intermediate scrutiny of the relevant statute should be employed. In order to apply intermediate equal protection review, a court must identify the purposes served by the law, determine whether they are important, and decide whether the statutory classification is substantially related to these government objectives.

In Price v. Cohen, the Third Circuit held that the state purposes served by the law are "to reallocate scarce welfare resources to those most in need, to encourage those best able to adjust to become independent and self-supporting, and to discourage fraud."16s Applying rationality scrutiny, the Price court held that these were legitimate state goals. ${ }^{158}$ These goals are also important, so they fulfill one criterion under the intermediate level of equal protection review.

In Price the court correctly held that the legislature could have rationally believed that the statutory classification served these goals. ${ }^{16 z}$ The Pennsylvania legislature heard testimony from the state Secretary of Welfare, who testified that most welfare recipients whom she considered employable were under the age of forty ${ }^{158}$ It also heard testimony from Governor Dukakis of Massachusetts, who outlined his state's experience with welfare reduction programs, and recommended that Pennsylvania retain general assistance for those forty-five and older. ${ }^{160}$

Although this testimony to the legislature indicates that the statutory classification has a conceivable rational basis, ${ }^{160}$ it does not establish a substantial relation between the legislative means and ends. Indeed, the testimony of the labor experts at trial demonstrated that the assumption that younger welfare recipients can more easily find work is false because there is no statistical correlation between age and em-

serious obstacle to them ever effectively organizing to increase their political power.

${ }^{15 s}$ Price, 715 F.2d at 94.

158 Id.

187 Id. at 96.

168 Supplemental Appendix, supra note 140, at 297a-298a.

109 Price, 715 F.2d at 95; see also Appendix, supra note 21, at 25a-27a.

160 To say that the age classification not only had a conceivable rational basis but also represented an inaccurate, prejudicial stereotype is not inconsistent. Many prejudices have a conceivable rational basis. For example, one stereotype that the Nazis exploited was that Jews were Communists. This prejudice had a conceivable rational basis since Jews were heavily represented on the first Politburo in Russia after the 1917 revolution and Jews were also prominent in the socialist uprisings in Germany after the First World War. For a discussion of the problem of distinguishing between prejudicial stereotypes that trigger heightened equal protection scrutiny and loose-fitting generalizations that pass constitutional muster under rationality scrutiny, see infra note 174. . 
ployability of welfare recipients.

Here, the distinction between rationality and intermediate review becomes crucial. Under rationality review, a court cannot reject a legislative viewpoint as "pure speculation"161 or require the state " to verify [its] logical assumptions with statistical evidence." "162 Under intermediate review, however, the Court has inquired at length into statistical correlations between the statutory classifications and goals and has required that the state present "credible supporting evidence" for its classification. ${ }^{163}$ Applying intermediate scrutiny, Plyler held that "the State must support its selection of this group as the appropriate target for exclusion." 164

In Price the state failed to make such a showing. The testimony by the state's expert, in light of contrary evidence by the labor experts, simply does not constitute credible supporting evidence that the statutory classification serves to reallocate scarce welfare resources to the most needy. Nor did the state present "credible supporting evidence" to demonstrate that the classification substantially furthered the goals of encouraging self-dependency and discouraging fraud. A labor expert testified that, since welfare recipients are disadvantaged by low levels of job skills and education, their chances of finding work within the three months before they are terminated from general assistance may be as low as between ten and twenty percent. ${ }^{165}$ As the district court noted in Price v. Cohen, "A person faced with no general assistance benefits and no employment prospects cannot learn self-dependence."168 The district court rejected the suggestion of state's counsel that the transitionally needy "could turn to friends and relatives for support," noting that the goal of self-dependence is not furthered in this manner. ${ }^{18 z}$

Finally, the state presented no evidence ${ }^{\mathbf{1 6 8}}$ indicating that younger

162 See supra notes $32-33$ and accompanying text.

182 Vance v. Bradley, 440 U.S. 93, 110 n.28 (1979) (quoting Hughes v. Alexandria Scrap Corp., 426 U.S. 794, 812 (1976)).

163 See supra note 31 and accompanying text.

104 Plyler v. Doe, 457 U.S. 202, 229 (1982).

16s Supplemental Appendix, supra note 140, at 246a. 1983).

166 Price v. Cohen, 565 F. Supp. 657, 662 (E.D. Pa.), rev'd, 715 F.2d 87 (3d Cir.

167 Id. at 661-62.

168 The Court for of Appeals for the Third Circuit in Price asserted that the state Secretary of Welfare, in testimony before the Pennsylvania legislature, "offered statistics purporting to show that these younger recipients . . . were much more likely to engage in welfare fraud." 715 F.2d at 95 . This assertion appears to be unfounded. A survey of the legislative testimony to which the court referred, see Supplemental Appendix, supra note 140 , at $293 a-337 a$, indicates that this legislative testimony did not include any statistics or arguments that younger recipients were more likely to commit fraud than older recipients. 
welfare recipients were more likely to engage in fraud than older recipients. The only evidence that remotely related to this issue was testimony by the state Secretary of Welfare to the Pennsylvania legislature indicating that forty-four percent of welfare fraud cases involved general assistance (the welfare assistance curtailed by the challenged statute in Price). ${ }^{108}$ However, this testimony did not indicate that younger recipients were more likely to commit fraud. Although the classification apparently would reduce fraud by removing approximately 60,000 to 90,000 transitionally need from general assistance, ${ }^{170}$ no evidence was presented that the exclusion of these younger recipients would reduce fraud more than any other arbitrary exclusion of 60,000 to 90,000 recipients.

Since the statutory classification in Pennsylvania's welfare statute is not substantially related to important state ends, it would be struck down under the intermediate standard of equal protection review.

\section{CONCLUSION}

Judicial review always has drawbacks in a democratic system premised on majority rule and government by elected representatives because judicial review is often countermajoritarian and unrepresentative. Indeed, given these costs, judicial review is justifiable only when necessary to protect constitutional values that have been trampled by the majoritarian process.

Unfortunately, judicial review of equal protection challenges to legislation is hard to justify in this respect. The mandate that all persons are entitled to equal protection of the laws is a noble sentiment largely devoid of content. ${ }^{171}$ The equal protection clause requires that people who are similarly situated in all relevant respects be treated equally, ${ }^{172}$ but it does not define what respects are relevant when determining whether people are similarly situated. ${ }^{173}$ Inevitably, in applying

168 Supplemental Appendix, supra note 140, at 299a.

170 See Brief for Appellees, supra note 19, at 2 n.1 (discussing how many transitionally needy would be terminated by the challenged statute). Even though the state produced no evidence that younger recipients were more likely to commit fraud, the court was still correct in holding that the Pennsylvania legislature could have rationally believed that the statutory classification furthered the goal of reducing fraud. Such a view has a conceivable rational basis if criminal behavior among adults in general tends to be positively correlated with young adulthood.

${ }_{171}$ See Westen, The Empty Idea of Equality, 95 HARv. L. REv. 537 (1982).

172 See, e.g., Royster Guano Co. v. Virginia, 253 U.S. 412, 415 (1920); Tussman \& tenBroeck, The Equal Protection of the Laws, 37 CALIF. L. REv. 341,344 (1949).

${ }_{173}$ For example, most judges would agree that people whose last names begin with different letters are similarly situated with respect to law that grants welfare benefits, but that people with a job and people without employment are not. 
the equal protection clause, judges must make substantive value choices, guided largely by their intuitive sense of what is just, to decide whether people who differ in a certain trait are similarly situated in all relevant respects with regard to a particular statutory purpose. ${ }^{\mathbf{1 7 4}}$

Heightened equal protection scrutiny, whether strict or intermediate, is a potent weapon that can easily be used to strike down legislative enactments and one that must be carefully controlled. This Comment responds to the need fo sharply limit judicial interventionism under the equal protection clause. In a fashion similar to the Court's decision in Plyler $v$. Doe, ${ }^{\mathbf{1 7 5}}$ intermediate scrutiny should only be applied in a narrow range of circumstances where the denial of subsistence (an important interest with a close nexus to constitutional rights) would result in the discriminatory infringement of the constitutional rights of a disfavored group and where the disfavored group has "sensitive" characteristics that indicate that the classification is likely to reflect prejudice. Both the breadth of review-the range of circumstances in which the

174 See Westen, supra note 171 , at 543-48. Tribe has noted that the principle of equality "makes non-circular commands and imposes non-empty constraints only to the degree that we are willing to posit substantive ideals to guide collective choice." $L$. TRIBE, supra note 3, \& 16-1, at 991.

Jeffrey Blattner has written an excellent article analyzing how the Court has applied five models of equal protection: protecting minorities from prejudice, requiring rationality, protecting specially disadvantaged groups, validating procedural equal protection, and mandating equal treatment with respect to fundamental interests. See Blattner, supra note 98. Blattner concludes that each of these models are " imperfect' in that they are dependent of an externally supplied vision of a proper allocation of rights and responsibilities among the branches of government, and between the government and the individual." According to Blattner, "[T]he Court's recent equal protection decisions are . . explicable only in terms of a judicially concealed substantive vision, described here as "just and unjust disadvantaging." " $I d$. at 780.

Blattner points out that the Court has been justifying heightened equal protection-both strict and intermediate-by the need to protect minorities from prejudice. See id. at 804-08. Yet he criticizes "prejudice" as an empty idea: "[w] hat is subsumed in the concept of 'prejudice' is a set of value judgments about when the government may or may not treat particular groups or individuals unequally. Only a judicially supplied definition of 'just and unjust disadvantaging' can give meaning to the . . . concept of prejudice." Id. at 812 .

Blattner's critique is especially relevant to this Comment inasmuch as the Comment, like Craig v. Boren, 429 U.S. 190 (1976), treats statutory use of a stereotype as an indication that the classification is sensitive and thus should be subjected to heightened scrutiny. See supra text accompanying note 138 . Nothing distinguishes a stereotype that triggers intermediate scrutiny from an overbroad, loose-fitting classification that is permissible under rationality scrutiny, except some externally supplied substantive vision that it is wrong to classify on the basis of a certain trait. See also The Puzzling Persistence of Process-Based Constitutional Theories, 89 YaLE L.J. 1063, 1075 (1980) ("TT]he conclusion that a legislative classification reveals prejudicial stereotypes must, at bottom, spring from a disagreement with the judgments that lie behind the stereotype.") These considerations indicate that the application of equal protection review necessarily involves infusion of judicially-supplied substantive values.

178457 U.S. 202 (1982). 
heightened review its applicable-and the depth of review-the rigorousness of the scrutiny applied-should be tightly restrained.

When particularly harsh welfare laws deny subsistence to a group with sensitive characteristics, the intermediate tier of review can be an important tool for the judiciary in scrutinizing those laws. For, after all the theoretical arguments have been made, it is important not to lose sight of the human tragedy of denials of subsistence. The plight of the tens of thousands of destitute Pennsylvanians, cut off from assistance by the statute challenged in Price $v$. Cohen, ${ }^{176}$ is well illustrated by the deprivation confronting Tammy Craig, a named plaintiff in that case:

Tammy Graig is 35 . She grew up in Florida where she attended a rural school for three years. She is unable to read, write or count. She has twice been employed as a security guard but was terminated when she was unable to take down telephone messages. In 1979, at the suggestion of the Department [of Public Welfare], she attended literacy classes for three months. She was cut off from general assistance in April as "transitionally" needy and was told that "there are no exceptions made for people like myself." She has been rejected from a training class for lack of a high school diploma and rejected from employment because she does not read, write or count. She will have to vacate her living quarters for failure to pay rent. "Shortly I will have no home, no food to eat and no place to go. What am I to do?"177 1983).

176 715 F.2d 87 (3d Cir. 1983), rev'g Price v. Cohen, 565 F. Supp. 657 (E.D. Pa.

177 Brief for Appellees, supra note 19, at 29 (summarizing affidavit by Tammy Craig in Appendix, supra note 21, at 154a-155a). 